\title{
PELATIHAN PENGGUNAAN KOMPONEN DIODA PADA RANGKAIAN ELEKTRONIKA BAGI MAHASISWA FAKULTAS ILMU KOMPUTER UNIVERSITAS LANCANG KUNING PEKANBARU
}

\author{
Atmam $^{1}$, Zulfahri $^{2}$, Usaha Situmeang ${ }^{3}$ \\ ${ }^{1,2,3}$ Program Studi Teknik Elektro, Fakultas Teknik, Universitas Lancang Kuning \\ Jl. Yos Sudarso km. 8 Rumbai, Pekanbaru, Telp. (0761) 52324 \\ e-mail: atmam@unilak.ac.id
}

\begin{abstract}
Faculty of Computer Science is one of the Faculty of the University of Lancang Kuning Pekanbaru, consists of 2 (two) study programs namely Information Systems and Informatics Engineering. Electronic Physics and Advanced Electronics is a compulsory subject for the students of Informatics Engineering Faculty of Computer Science. This course provides an understanding of electronics components. Theoretically, Informatics Engineering students have obtained material about the electronic component. However, the mastery of electronics is not separated by the process of practicum. The problem that occurs is the lack of mastery of electronics in practice. Currently, the practicum process has not been implemented and has an impact on the lack of students' ability in terms of electronics practice. Seeing these conditions then there should be efforts to equip students in the Information Engineering practically in the use of electronic components. One of the knowledge and skills is the use of electronics components in simple circuit is through the training of diode usage in rectifier circuit. The result of this community service activity is the participants' knowledge about electronic defenisi, $100 \%$ of participants already know it with $8 \%$ increase and the knowledge of electronic component from participant is increase $24 \%$. The participants' knowledge about the use of diodes in the rectifier circuit is $72 \%$ and the participants already know the technique of electronic component soldering which is initially $24 \%$ and an increase of $76 \%$.
\end{abstract}

Keywords-Electronics, diode, rectifier

\begin{abstract}
Abstrak
Fakultas Ilmu Komputer adalah salah satu Fakultas di Universitas Lancang Kuning Pekanbaru, terdiri dari 2 (dua) program studi yaitu Sistem Informasi dan Teknik Informatika. Fisika Elektronika dan Elektronika Lanjut adalah mata kuliah wajib bagi mahasiswa Teknik Informatika Fakultas Ilmu Komputer. Mata kuliah ini memberikan pemahaman tentang komponen elektronika. Secara teoritis mahasiswa Teknik Informatika telah memperoleh materi tentang komponen elektronika tersebut. Namun, penguasaan ilmu elektronika ini tidak terlepas dengan adanya proses praktikum. Permasalahan yang terjadi adalah kurangnya penguasaan ilmu elektronika secara praktek. Saat ini, proses praktikum belum dilaksanakan dan berdampak kepada kurangnya kemampuan mahasiswa dari segi praktek elektronika. Melihat kondisi tersebut maka haruslah ada upaya untuk membekali mahasiswa Teknik Informatika secara praktis dalam penggunaan komponen elektronika. Salah satu pengetahuan dan keterampilan adalah penggunaan komponen elektronika pada rangkaian sederhana adalah melalui pemberian pelatihan penggunaan dioda pada rangkaian penyearah. Hasil Kegiatan pengabdian kepada masyarakat ini adalah pengetahuan peserta tentang defenisi elektronika, $100 \%$ peserta sudah mengetahuinya dengan peningkatan sebesar $8 \%$ serta pengetahuan komponen elektronika dari peserta terjadi peningkatan sebesar 24\%. Peningkatan pengetahuan peserta tentang penggunaan dioda pada rangkaian penyearah sebesar $72 \%$ dan peserta sudah mengetahui teknik penyolderan komponen elektronika dimana awalnya $24 \%$ dan terjadi peningkatan sebesar $76 \%$.
\end{abstract}

Kata kunci-Elektronika, Dioda, Penyearah 


\section{PENDAHULUAN}

Fakultas Ilmu Komputer adalah salah satu Fakultas yang ada di Universitas Lancang Kuning Pekanbaru dan disingkat UNILAK serta merupakan salah satu Universitas swasta yang ada di Kopertis wilayah X. Fakultas Ilmu Komputer terdiri dari 2 (dua) program studi yaitu Sistem Informasi dan Teknik Informatika. Fisika Elektronika dan Elektronika Lanjut adalah mata kuliah wajib yang harus diambil oleh mahasiswa Teknik Informatika Fakultas Ilmu Komputer Universitas Lancang Kuning Pekanbaru. Mata kuliah ini memberikan pemahaman tentang komponen elektronika yang terdiri dari komponen aktif dan komponen pasif serta aplikasinya dalam rangkaian sederhana sehingga dapat dijadikan sebagai pendukung pada mata kuliah berikutnya.

Secara teoritis mahasiswa Teknik Informatika telah memperoleh materi tentang komponen elektronika tersebut. Namun demikian, penguasaan ilmu elektronika ini tidak terlepas dengan adanya proses praktikum khususnya tentang penggunaan komponen elektronika pada rangkaian sederhana. Saat ini, proses praktikum dari mata kuliah di atas belum dilaksanakan bagi mahasiswa Teknik Informatika. Hal ini tentunya akan berdampak kepada kurangnya kemampuan mahasiswa dari segi praktek dalam menguasai elektronika. Salah satunya adalah penerapan penggunaan komponen elektronika berupa dioda pada rangkaian sederhana seperti rangkaian penyearah.

Melihat kondisi tersebut, dan juga adanya mata kuliah lanjutan yang memerlukan ilmu elektronika sebagai pendukung, maka haruslah ada upaya untuk membekali mahasiswa Teknik Informatika dengan kemampuan secara praktis dalam penggunaan komponen elektronika. Salah satu pengetahuan dan keterampilan yang berhubungan dengan penggunaan komponen elektronika pada rangkaian sederhana adalah melalui pemberian pelatihan penggunaan dioda pada rangkaian penyearah.

Dioda merupakan komponen elektronik yang berfungsi untuk melewatkan arus hanya ke satu arah saja. Dioda memegang peranan penting dalam elektronika, diantaranya adalah menghasilkan tegangan searah dari tegangan bolak-balik. Dioda adalah komponen elektronik yang dibuat dari bahan semikonduktor (silikon atau germanium) tipe $p$ dan tipe $n$ yang disatukan. Dioda memiliki dua konduktor yaitu anoda yang dihubungkan pada sumber tegangan positif dan katoda yang dihubungkan pada sumber negatif [1-6]. Pada penerapannya komponen dapat digunakan sebagai penyearah yaitu suatu alat yang terdiri dari saklar-saklar daya disusun sedemikian rupa sehingga dapat merubah energi listrik tegangan bolak-balik (AC) menjadi energi listrik tegangan arus searah (DC) [7].

Dari hasil kegiatan ini diharapkan mahasiswa mampu dalam menerapkan penggunaan komponen dioda pada rangkaian penyearah, sehingga kedepannya akan dapat mendukung mata kuliah yang ada hubungannya dengan komponen elektronika.

\section{METODE}

Metode pelaksanaan yang digunakan dalam kegiatan ini adalah:

1. Penyuluhan.

Memberikan teori dasar tentang tentang pengertian elektronika, sejarah elektronika, komponen elektronika dan penggunaan dioda pada rangkaian penyearah, cara-cara membaca rangkaian penyearah yang terdiri dari beberapa komponen seperti trafo, dioda, resistor dan kapasitor serta penyuluhan tentang teknik penyolderan komponen elektronika.

2. Pelatihan

Mahasiswa melakukan praktek secara langsung penggunaan dioda untuk rangkaian penyearah, pengujian rangkaian penyearah di dampingi oleh tim pelaksana pengabdian kepada masyarakat.

3. Evaluasi

Teknik mengevaluasi hasil kegiatan adalah dengan memberikan kuisioner kepada peserta yang mencakup seluruh materi sebelum dan sesudah pelatihan. 


\section{HASIL DAN PEMBAHASAN}

\subsection{Hasil}

Kegiatan pengabdian kepada masyarakat ini di ikuti oleh Mahasiswa Program Studi Teknik Informatika Fakultas Ilmu Komputer Universitas Lancang Kuning Pekanbaru yang dilaksanakan pada tanggal 27 Maret 2018. Adapun jumlah peserta yang hadir pada kegiatan ini adalah 26 orang dan kuisioner yang diberikan adalah untuk 25 orang. Dari hasil evaluasi pelaksanaan penyuluhan ini melalui Pre-Test dan Post-Test, dapat dikatakan berjalan dengan baik, karena dari peserta yang hadir sebanyak 25 orang menjawab kuisioner yang diberikan.

Pada gambar 1 peserta menyimak materi yang diberikan oleh tim pengabdian masyarakat tentang penggunaan komponen dioda pada rangkaian elektronika dan setelah pemberian materi dilanjutkan dengan diskusi dengan peserta dengan melakukan tanya jawab tentang materi yang diberikan.

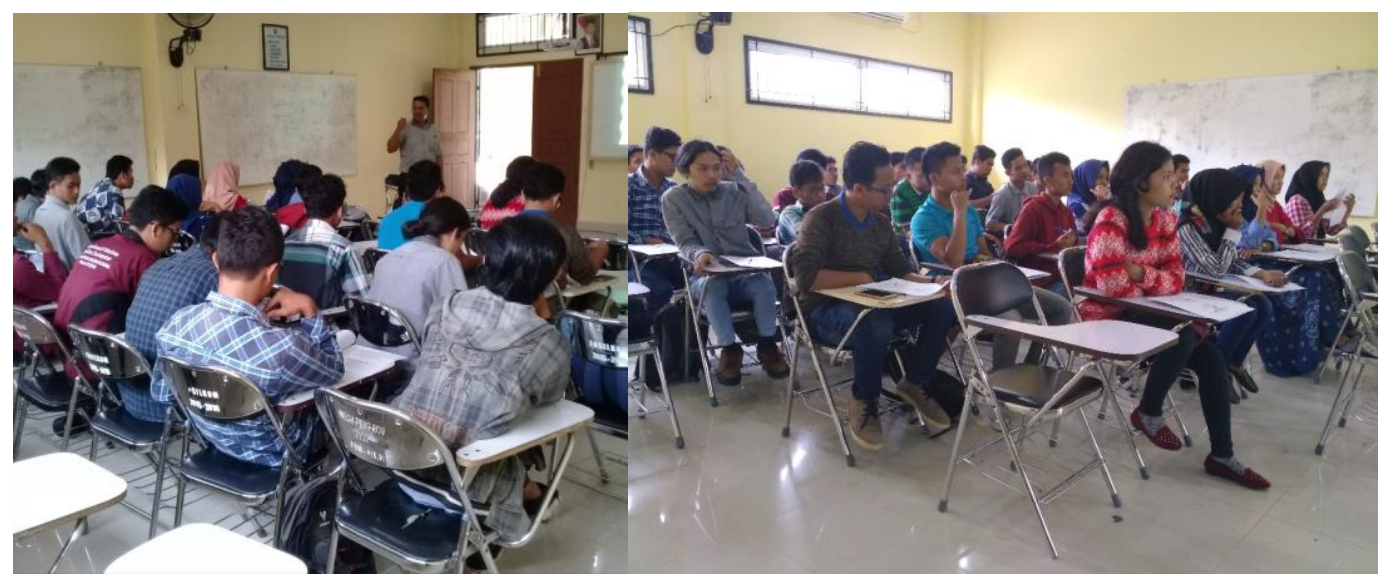

Gambar 1. Peserta pelatihan dan pemberian materi

Kegiatan berikut yang dilakukan adalah peserta melaksanakan praktek secara langsung penggunaan dioda untuk rangkaian penyearah yang didampingi oleh tim pengabdian kepada masyarakat. Pelaksanaan kegiatan penggunaan dioda untuk rangkaian penyearah bagi peserta atau mahasiswa dibagi menjadi lima kelompok. Setiap kelompok mendapatkan pengetahuan langsung tentang penggunaan dioda untuk rangkaian penyearah dan mengetahui serta mempraktekan secara langsung teknik penyolderan penggunaan dioda untuk rangkaian penyearah yang didampingi oleh tim pengabdian kepada masyarakat. Kegiatan praktek penggunaan dioda untuk rangkaian penyearah yang dilakukan oleh peserta seperti terlihat pada Gambar 2.

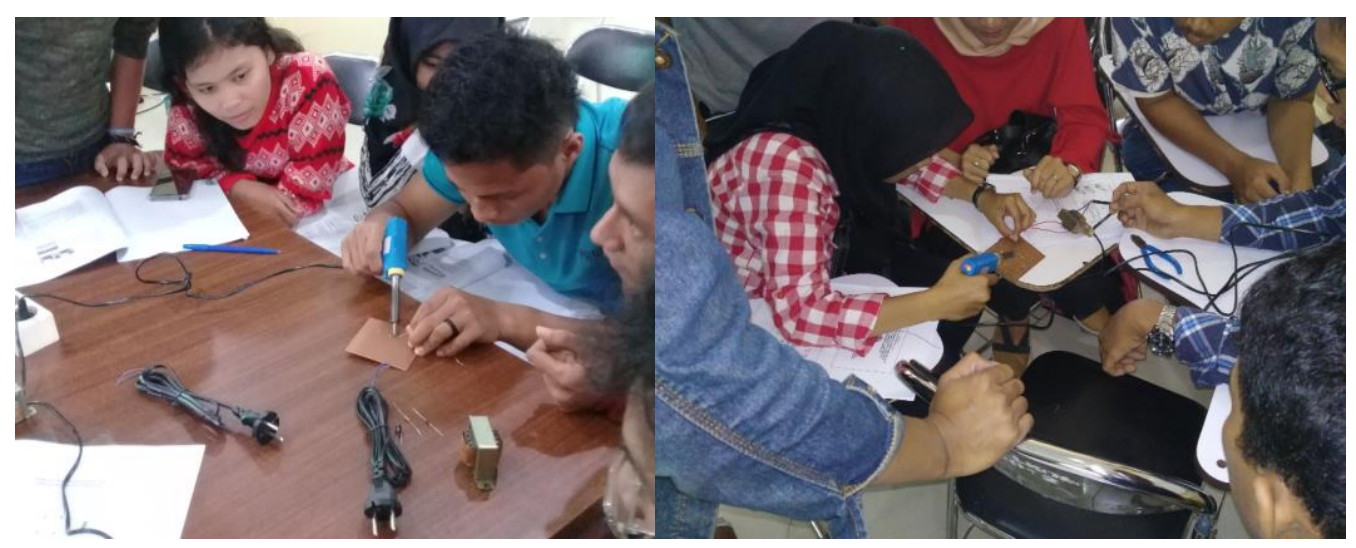

Gambar 2. Peserta melakukan pembuatan rectifier menggunakan komponen dioda didampingi Tim Pengabdian 
Untuk mengevaluasi kegiatan maka dilakukan dengan pemberian kuisioner kepada peserta dan hasil kuisioner seperti pada tabel 1 dan setelah selesai ceramah dilaksanakan, diadakan kesempatan untuk bertanya atau diskusi, tentang pelatihan penggunaan dioda untuk rangkaian penyearah, kemudian dilanjutkan dengan memberikan visualisasi tentang komponen elektronika yang diguanakan dalam pembuatan penyearah.

Tabel 1. Hasil Pre-Test dan Post-Test kegiatan

\begin{tabular}{|c|c|c|c|c|c|}
\hline \multirow{2}{*}{ Pertanyaan } & \multicolumn{2}{|c|}{ Pre Test (\%) } & \multicolumn{2}{|c|}{ Post Test (\%) } & \multirow{2}{*}{$\begin{array}{l}\text { Peningkatan } \\
(\%)\end{array}$} \\
\hline & $\mathrm{Ya}$ & Tidak & $\mathrm{Ya}$ & Tidak & \\
\hline $\begin{array}{l}\text { 1. Apakah anda mengetahui tentang } \\
\text { defenisi elektronika? }\end{array}$ & 92 & 8 & 100 & 0 & 8 \\
\hline $\begin{array}{l}\text { 2. Apakah anda mengetahui tentang } \\
\text { komponen elektronika? }\end{array}$ & 76 & 24 & 100 & 0 & 24 \\
\hline $\begin{array}{l}\text { 3. Apakah anda mengetahui tentang } \\
\text { Dioda? }\end{array}$ & 64 & 36 & 100 & 0 & 36 \\
\hline $\begin{array}{l}\text { 4. Apakah anda mengetahui penggunaan } \\
\text { dioda pada rangkaian penyearah ? }\end{array}$ & 24 & 76 & 96 & 4 & 72 \\
\hline $\begin{array}{l}\text { 5. Apakah anda pernah membuat } \\
\text { rangkaian penyearah? }\end{array}$ & 0 & 100 & 96 & 4 & 96 \\
\hline $\begin{array}{l}\text { 6. Apakah anda mengetahui teknik } \\
\text { penyolderan komponen elektronika? }\end{array}$ & 24 & 76 & 100 & 0 & 76 \\
\hline $\begin{array}{l}\text { 7. Apakah anda mengetahui pengujian } \\
\text { rangkaian penyearah? }\end{array}$ & 4 & 96 & 100 & 0 & 96 \\
\hline $\begin{array}{l}\text { 8. Apakah anda puas terhadap } \\
\text { pelaksanaan acara pelatihan ini? }\end{array}$ & - & - & 100 & 0 & 100 \\
\hline
\end{tabular}

\subsection{Pembahasan}

Hasil Pre-Test yang dilaksanakan sebelum penyuluhan menunjukkan bahwa peserta atau mahasiswa mengetahui tentang defenisi elektronika sebanyak 23 orang atau $92 \%$ dan $8 \%$ tidak mengetahui tentang defenisi elektronika. Pengetahuan peserta atau mahasiswa tentang komponen elektronika sebesar $76 \%$ peserta yang mengetahui dan $24 \%$ tidak mengetahui. Hal ini dikarenakan mahasiswa telah pernah mengikuti mata kuliah dasar elektronika berupa teori semasa perkuliahan

Untuk pertanyaan kuisioner : Apakah anda mengetahui tentang Dioda? 36\% peserta (9 orang) menjawab tidak mengetahui tentang Dioda. Selanjutnya, pertanyaan: "Apakah anda mengetahui penggunaan dioda pada rangkaian penyearah?", 6 peserta menjawab "Ya" dan 76 peserta menjawab "Tidak" sehingga dapat dipresentasikan bahwa $76 \%$ peserta tidak mengetahui tentang penggunaan dioda pada rangkaian penyearah. Kondisi pengetahuan tentang penggunaan dioda pada rangkaian penyearah dari mahasiswa terjadi demikian dikarenakan bahwa saat perkuliahan elektronika hanya diberikan dasarnya saja dan tidak termasuk aplikasinya.

Dari pertanyaan : "Apakah anda pernah membuat rangkaian penyearah?". Hasil yang diperoleh bahwa seluruh peserta ( 25 orang) menjawab "Tidak". Secara persentase bahwa $100 \%$ peserta tidak pernah membuat rangkaian penyearah. Untuk pertanyaan "Apakah anda mengetahui teknik penyolderan komponen elektronika?", dan dari peserta yang mengisi kuisioner, $76 \%$ tidak mengetahuinya dan $24 \%$ mengetahui serta belum pernah mempraktekannya. Untuk pertanyaan: "Apakah anda mengetahui pengujian rangkaian penyearah?", peserta menjawab tidak (96\%) dan menjawab ya sebesar $4 \%$. Pengetahuan dan keterampilan ini memang tidak dimiliki oleh mahasiswa karena tidak dipraktekan selama perkuliahan.

Hasil Post Test yang dilaksanakan setelah penyuluhan dan pelatihan menunjukkan bahwa pengetahuan peserta tentang defenisi elektronika sudah menunjukkan perubahan dari tidak mengetahui $(8 \%)$ menjadi mengetahui $(100 \%)$ dan terjadi peningkatan $8 \%$. Pengetahuan tentang komponen elektronika, juga sudah mengalami peningkatan yaitu $24 \%$ peserta sudah mengetahui dimana awalnya hanya $24 \%$ peserta yang mengetahuinya. Selanjutnya dari pertanyaan tentang: Apakah anda mengetahui tentang Dioda?, dari jawaban yang diberikan $100 \%$ sudah mengetahuinya dan terjadi peningkatan sebesar 36\%. Untuk pertanyaan: "Apakah anda mengetahui 
penggunaan dioda pada rangkaian penyearah?" dari jawaban yang diberikan $100 \%$ sudah mengetahuinya dan terjadi peningkatan sebesar $72 \%$. Dari pertanyaan tentang : "Apakah anda pernah membuat rangkaian penyearah?" telah terjadi peningkatan $96 \%$ dimana awalnya seluruh peserta atau mahasiswa tidak pernah membuat rangkaian penyearah.

Dari pertanyaan tentang : "Apakah anda mengetahui teknik penyolderan komponen elektronika?", $100 \%$ peserta sudah mengetahuinya dimana awalnya hanya $24 \%$, sehingga terjadi peningkatan sebesar $76 \%$. Kemudian untuk pertanyaan: "Apakah anda mengetahui pengujian rangkaian penyearah?", maka setelah dilakukan penyampaian materi penyuluhan, $100 \%$ sudah mengetahuinya dan terjadi peningkatan pengetahuan sebesar 96\%. Untuk tingkat keberhasilan dan kepuasan dari acara pengabdian masyarakat ini tentang Pelatihan Penggunaan Komponen Dioda Pada Rangkaian Elektronika Bagi Mahasiswa Fakultas Ilmu Komputer Universitas Lancang Kuning Pekanbaru, $100 \%$ peserta menyatakan puas dengan menjawab "Ya" pada lembar kuisioner post-test.

\section{KESIMPULAN}

1 Pengetahuan peserta tentang defenisi elektronika, $100 \%$ peserta sudah mengetahuinya dengan peningkatan sebesar 8\% serta pengetahuan komponen elektronika dari peserta terjadi peningkatan sebesar $24 \%$.

2 Peningkatan pengetahuan peserta tentang penggunaan dioda pada rangkaian penyearah sebesar $72 \%$ dan peserta sudah mengetahui teknik penyolderan komponen elektronika dimana awalnya $24 \%$ dan terjadi peningkatan sebesar $76 \%$.

\section{SARAN}

1 Dari hasil kegiatan penyuluhan dan pelatihan diharapkan peserta dapat mempelajari dan melatih ulang tentang elektronika khususnya penggunaan komponen dioda pada rangkaian penyearah.

2 Dari hasil kegiatan, diperlukan penyuluhan dan pelatihan yang sama untuk mahasiswa Fakultas Ilmu Komputer secara berke-sinambungan.

\section{UCAPAN TERIMA KASIH}

Penulis mengucapkan terima kasih kepada semua pihak yang telah memberi dukungan financial terhadap kegiatan ini.

\section{DAFTAR PUSTAKA}

[1] D.Chattopadhyay, PC Rakshit, B Saha, NN Purkait, 1989, Dasar Elektronika, Universitas Indonesia.

[2] Ganti Depari, 2000, Pokok-pokok Elektronika, M2S Bandung.

[3] Malvino, 2003, Prinsip-prinsip Elektronika, Salemba Teknika.

[4] Sutrino, 1986, Elektronika (Teori dan Penerapannya), Penerbit ITB.

[5] Thomas Sri Widodo, 2002, Elektronika Dasar, Penerbit Salemba Teknika.

[6] Wasito, 2004, Vademekum Elektronika, Penerbit PT. Gramedia Pustaka Utama.

[7] Yuli Asmi Rahman, 2011, Aplikasi Karakteristik Penyearah Satu Fase Terkendali Pulse Width Modulation (PWM) pada beban resistif, Jurnal SMARTek, Vol. 9 No.1 